\title{
The Church
}

The Church...Ancient Secrets...A Loveolution...a touch of the pre-Big Bang pre-Universe Eternity Statimuum--messages from God to wake up because THERE IS MORE THAN THIS earthly CRAZINESS...The Church gives a touch of the "other" world--a "new covenant" and "not belonging to this creation"--a living touch of the pre-BigBang Eternity...to which we will return at the recompression called "death".

The Church seems to be the only organization committed to "Nature and Nature's God" which gives it life and synchrony with the universe, so much so, that it is the only group which professes linkage with the pre-Big Bang Eternity of a Loving Transcendent God waiting for our return enabled by Jesus if freely followed by each of us. The Church has not lasted over two millennia because it has done all the bad which the anti-s accuse. Even though criticisms are usually uncharitable and magnified, the Church rebutts all criticisms, but the complainers have proven so deaf that the Church rarely bothers with the same old stale attacks any more. And sometimes, the rebuttals fall flat, because the leaders are human and imperfect. And those who criticize have closed minds and do not want the truth. Regardless, the Church somehow stays afloat with a big rudder and bumbling crew. As my father would always say, "The Church must be divine to survive even 50 years with the leadership it always has." It does not help being filled with sinners trying to be healed by mercy and forgiveness. Maybe it has to do with Jesus creating it: Mathew 16:18 properly translated from Aramaic (to Simon Peter, "You are Kephas, and on the kephas I will build my church.") or from Greek, "You are Petros (male word needed for Peter), and on this petras ("rock" is grammatically feminine in Greek), I will build by church." There is no reasonable questioning the creation of the Church by Jesus, nor its identification with the Body of Christ from about 22 other verses.

A major characteristic of the Church is that it is the oldest organization routinely antagonizing all because it says there are "sins", which means that one must assume responsibility for wrongdoing. It will speak up; it must speak up; it should speak up. It does so by a discrete clarity and gets condemned for both, i.e., trying to being too discrete and being too clear, depending on who is hearing-the Church is always "not enough" or "too much". No one wants to hear such, so, not surprisingly, they attack the Church any way possible-it is sort of a "how dare you tell me I am wrong or right" kind of automatic reaction. Also, it is the oldest group doing this by synchrony with the environment, the animal kingdom, the earth, and the universe by commitments to Nature and Natural Law morality-and, again, people have an almost automatic tendency to pollute physically and behaviorally (original sin again), so they do not like to be told they are out of synchrony with the planet either (original sin as usual) especially by legitimate authority trying to overcome original sin. Also, the Church is the oldest organization promoting Life, Liberty, and Pursuit of Happiness, metaphorically at least as Father, Son, and

Volume 4 Issue 3 - 2015
Dr. Samuel A Nigro M.D*
Retired, Assistant Clinical Professor Psychiatry, Case Western
Reserve University School of Medicine, USA
*Corresponding author: Dr. Samuel A Nigro M.D, Retired,
Assistant Clinical Professor Psychiatry, Case Western Reserve
University School of Medicine, 2517 Guilford Road, Cleveland
Heights, Ohio 44118, USA, Tel: 216 932-0575; Email:
sam@docnigro.com
Received: October 15, 2015 | Published: November 24,
2015

Holy Spirit. It is the oldest Transcendental organization ever which promotes Being, Matter, Identity, Truth, Oneness, Good and Beauty. It is the oldest organization promoting Liberty and Love for all. It is the oldest democracy in the world electing its leader. It brings a touch of "another World" which is why it is sometimes difficult to understand, embrace and actively participate in.

From contemporary science which it created, the Church is committed to the physics of the Big Bang and to the pre- and post- Big Bang called "the Statimuum" (or traditionally the "Beautific Vision"). It believes in the "Big Bust-up" of Adam and Eve's freedom to choose against biology and biochemistry, and thereby began the potential to sin in every human. The Church originated from and is committed to the "Big Bailout" of Jesus as Incarnation, at the Last Supper, on the Cross, and Resurrection. By the Sacraments, it brings a touch of the Pre-Big Bang (the Statimuum, in physics) into the world and avers that the miracles are examples of the Statimuum also. The Church tries to be transcendentally identical to Jesus as the Body of Christ by Grace and by the Seven Sacraments as " $2 \mathrm{X} 4 \mathrm{~s}$ up side the head" trying to wake everyone up (and no one likes that either) in a peaceful and merciful way. The job is impossible given original sin, but it is the only organization so committed. The Church is a LOVEOLUTION... unique, ancient, mysterious--that there is more. The Church is an ongoing "touch" of the pre-Universe by divinely given metaphors about "why you are you."

In summary, the Church is an always sinking barque ponderously floating to a pre-Big Bang world advertised as "There is unbelievably more than this craziness in which we are living." One-third of the Church crew is always in blundering mutiny (one in 12 is a traitor); one-third confused; and one-third paddling (with 8 oars-Baptism, Penance, Holy Communion, Confirmation, Extreme Unction, Holy Orders, Matrimony, and Grace) like their lives depend on it, because it does for all including millions of 
passengers, of whom one-third are unwittingly or arrogantly poking holes in the hull; one-third are plugging holes; and one-third are savoring the ride by reliving the Last Supper, by Sacramental living, and by living the Last Words of Christ. In a way, the leaders of the Church do not really count and certainly celebrities are almost irrelevant no matter who they are-especially if they are non-believing teachers of "there is nothing but biology, biochemistry, and matter" (but they contradict themselves whenever they celebrate birthdays among other events beyond the capacity of subhuman matter-confined non-spiritual animals). Basically, the Spiritual messages are what count, especially the Mass Mantra participated in by actively phrasing 2000 year old WORDS of ancient secrets, which somehow seem suppressed by the contemporary electronic-celluloid-ink culture of celebrity, violence, unNaturalness, disgust and selfish arrogance. For the Church, words are angels--matter/form compounds which should, properly used, spiritualize the world enabling return to the pre-BigBang Eternity with an unimaginable Statimuum with God.

Its most effective message is the Mass Mantra of: "Break the bread and bless the wine and join Jesus and all others so sanctified in a Statimuum of all with all and for all, Incarnated by Life, Sacrifice, Virtue, Love, Humanity, Peace, Freedom, and Death without Fear, in the universe received and receiving one time for all time praising God in unlimited Spirituality of Consubstantiation Transubstantiation. Amen." Just listen and understand the words of the songs of the
Church. Provided are "reality metaphors enabling the good life by knowing who you are and why" better than those from any other person or group. Without Christian virtues, overt or covert, as part of any culture, nothing will work because too many people will be no good and there will be insufficient traditional "family" love for civilized and pro-social living. "Laws" will be needed instead.

Thus, somehow, criticisms of the Church fall flat over time, because the criticisms are from those who do not want to understand or have other agenda, usually fiendishly selfish and self-righteously denying of wrongdoing, while they encourage others to commit acts of varying degrees of evil (understood in physics as willful entropy). Usually attacking the Church is to distract from evil seductively promoted by the person attacking the Church--What lies have you heard about the Church? Was not the anti-Catholic bigotry learned from someone who wants to control you--by self-promoting deliberately dishonest bravado turning you into a robot-like mindless lie-driven promoter of entropy if not hate, and hardened your heart against the good and holy ancient secrets of good humanity at the same time?

To get a better understanding of the scientific basis for all this may be found in my books, Everybody for Everybody and Soul of the Earth. The Theogeocalculus on the Web should help too. Checking out Matthew 26, 26-30; Mark 14, 22-25; Luke 22, 19-20; John 6, 41 -59; and 1 Corinthians 11, 23-26 will help. Also check PeaceMercy.com for semi-secular version. 